\title{
Amaç Yönelimi ve Tükenmişlik Arasındaki Iliş̧kide Amaç İkliminin Moderatör Etkisi
}

\section{The Moderator Effect Of Goal Climate On The Relationship Between Goal Orientation And Burnout}

\author{
Rabia KÖSEOĞLU', Halis DEMIR²
}

\begin{abstract}
ÖZET
Başarı amaç yönelimi ve algılanan iklim uyumunun çalışanları tükenmişlikten koruyup koruyamayacağını araştıran bu çalıșma, banka çalışanlarından 400 çalışanın oluşturduğu bir örneklem üzerinde yürütülmüştür. Çalışmada amaç yönelimi ve tükenmişlik arasındaki ilişki üzerinde amaç ikliminin düzenleyici rolü araştııılmıs; ego ve görev yönelimli çalışanların, ego veya görev iklimi içinde bulunmalarının onların tükenmişlik düzeyleri üzerinde nasıl bir etki yapacağı inceleme konusu yapılmıştır. Araştırma bulgularına göre, sadece ego yönelimi ve duygusal tükenmişlik arasındaki ilişkide ego ikliminin düzenleyici rolüne kanıt sağlanmıştır. Çalışmamızın ana sorunsalına bağı olarak bu bulgu yorumlandığında, örneklemimizi oluşturan banka çalışanlarından ego yönelimine sahip olanların yüksek düzeyli ego iklimini yansıtan bir örgüt ikliminde çalışmaları durumunda duygusal tükenmişliklerinin azalacağına işaret etmektedir. Bulgular, ayrıca karşıt biçimde, ego yönelimli çalışanların düşük ego iklimi algıladıkları durumda da duygusal tükenmişliğin artacağını göstermektedir.
\end{abstract}

Anahtar Kelimeler: Ego Yönelimi, Görev Yönelimi, Ego İklimi, Görev İklimi, Tükenmişlik

\section{GíRiş}

Maslow (1943) motivasyon teorisinin önermelerini ileri sürerken; “...güdülerin sınıflandırılması... daha çok amaçlarüzerinetemellenmelidir"ve"...güdülersadece davranışın belirleyicilerinin bir sınıflandırmasıdır... davranış... hemen hemen her zaman biyolojik, kültürel ve koşul bağımlı olarak da belirlenmektedir" ifadelerini kullanmaktadır. Motivasyonu; "kişinin inançları tarafından hizmet edilen psikolojik olgularla ilişki" olarak ele alan Snyder motivasyonun "psikolojik olguyu üreten ve altında yatan güdüler, planlar, amaçlar, ihtiyaçlar ve nedenlerle ilişkili

\begin{abstract}
This study, which is intended to find out whether achievement goal orientation and employees' harmony with the perceived organizational climate would protect the employees from burnout, was carried out on a sample of 400 bank employees. In the present study, the moderator role of goal climate in the relation between goal orientation and burnout is investigated and the way the employment of ego-oriented employees and task-oriented ones in ego-involving and taskinvolving climates affects their levels of burnout is analysed. In the findings of the study, the evidence of the moderator role of ego-involving climate was detected only in the relation between ego orientation and emotional exhaustion. When interpreted on the basis of the main problematic of our study, this finding demonstrates that the level of emotional exhaustion felt by the ego-oriented bank employees in our sample decreases when they are employed in an organization with a highlevel ego climate. The findings also suggest that the ego-oriented employees show high levels of emotional exhaustion when they work in climates with low level of ego.
\end{abstract}

Key Word : Ego Orientation, Task Orientation, Ego Climate, Task Climate, Burnout

olduğunu", "farklı insanların oldukça farklı psikolojik fonksiyonlara hizmet etmek için aynı davranışları sergileyebileceklerini" ve "yüzeyde oldukça benzer olarak görülen eylemlerin kayda değer şekilde altta yatan oldukça farklı güdüleri yansıtabileceklerini" ileri sürmüştür (Snyder, 1993). Başarı motivasyonu alanındaki bilişsel teoriler motivasyonun amaç yönelimli aktivitelerin nedenleriyle ilişkili olduğunu ileri sürerken, amaç perspektifindeki değişimlerin; kişinin nasıl davranacağı, ne hissedeceği ve başarı konteksti içinde yeteneklerini nasıl bir süreç içinde düzenleyeceği ile ilişkili olduğunu iddia etmektedirler (Nicholls, 1984; 1989'dan aktaran Duda, 1989). 
Başarının (bir işi başarma) insanların temel ihtiyaçlarından biri olduğunu ileri süren Murray başarma güdüsünü doğuran bu ihtiyacl, "engelleri aşmak, gücünü göstermek, güç bir şeyi yapmak ve bunu mümkün olduğu kadar çabuk tamamlamak için mücadele etmek ve çaba sarf etmek olarak tanımlamaktadır (Murray,2008). Literatürde, bireyin başarma-tamamlama-erişme davranışının yönünü şiddetini ve devamlıı̆ını ifade etmek üzere kullanılan hipotetik (farazi) bir kavram olan başarma güdüsü; "ona ulaşmak için belirli bir gayreti gerektiren belirli bir hedefe başarılı bir şekilde erişme eğilimi" olarak tarif edilebilir (Arık, 1996). İddialı ya da zorlu koşullar karşısında çaba ve sebat davranışlarını açıklamaya yönelik girişimler, başarı amaç yönelimi kavramına temel oluşturmaktadır. Başarı hedefi kuramı yaklaşımları "Eklektik Yaklaşım" olan "Sosyal Bilişsel Teori" olarak isimlendirilen sınıfa düşer (Wyner, 2004; Dweck, 1986). Bu yaklaşımlar, sosyaldir çünkü bu yaklaşımlarda kişiler arası düşünce ve eylemin kökeni üzerinde durulmaktadır, bilişseldir çünkü bu yaklaşımlarda düşüncenin davranış üzerinde güçlü bir arabuluculuk rolü olduğu varsayılmaktadır (Wyner, 2004).

Amaç yönelimi literatürü incelendiğinde, çalışmalarda farklı adlandırmalarla genel olarak başlıca iki tip amaç yönelimi tanımlanmıştır. Amaç yönelimleri; bazı çalışmalarda ego-görev yönelimi (Jagacinski ve Nicholls, 1984; Duda, 1989; Nicholls, 1978), bazılarında da içsel motivasyon- dışsal motivasyon (Amorose ve Horn, 2000), bazılarında bireysel-rekabetçi hed ef yapıları (Ames ve Ames, 1981; Deci, 1971; Deci, 1972), bazılarında performans-öğrenme (Dweck ve Leggett, 1988) ve bazılarında performans-ustalık yönelimi (Ames ve Archer, 1988; Dweck, 1986 ) ve bazılarında da koruyucu-gelişim odaklı olma (Higgins, 2000, 2005) olarak tanımlanmıştır. Bu çalışmada amaç yönelimleri; ego ve görev yönelimi olarak ele alınmıştır.

Ego yöneliminde becerinin değişmez bir varlık olduğuna; görev yöneliminde ise becerinin işlenebilir, geliştirilebilir olduğuna yönelik bir inanç vardır (Elliot, 2005; Dweck ve Leggett, 1988). Ego yöneliminde; sonuca odaklı, daha az çabayla diğerlerini geride bırakarak daha yetenekli olduğunu kanıtlamaya odaklı dışsal bir güdü; görev yöneliminde ise beceriyi geliştirmek üzerine çaba sarf etmeye odaklı içsel bir güdü söz konusudur (Wyner, 2004; Dweck ve Leggett, 1988). Ego yöneliminde başarısızlık yetenek eksikliği anlamına geldiği için çaresizlik hissine neden olurken, aynı durum görev yöneliminde gelişim süreci ve ustalaşma konusunda fayda sağlayacak bilgi olarak yorumlanır (Elliot, 2005; Dweck ve Leggett, 1988, ).

Başarı motivasyonu üzerine yapılan araştırmalar, başarının sağladığı bireysel tatminden, başarının teşvik edildiği ödüllendirildiği iklime kaymıştır (McClelland, 1970). Araştırmacılar artan bir şekilde davranışı; hem kişiliğin hem de durumsal ya da çevresel faktörlerin ortak bir ürünü olarak düşünen, karşılıklı etkileşim yaklaşımı içinde değerlendirmeyi benimsemektedirler. Etkileşim paradigması, davranışın başlıca ya da tamamlayıcı nedenleri olarak, kişisel ya da durumsal faktörleri spesifik hale getirmeksizin; her ikisini birlikte davranış belirleyicisi olarak ele almaktadır (Martens vd., 1990). Higgins düzenleyici uyum teorisinde; bir eylemin (davranışın), kişinin yönelimi ve o eylemi sürdürmek için kullanılan araçlar (durumsal faktörler) arasındaki ilişkiler üzerine kurulu olduğunu ileri sürmektedir(2000;2005).

Bu çalışmada koşul bağımlııklar olarak, iki amaç yönelimine bağlı olarak iki amaç iklimi seçilmiştir: Ego iklimi ve görev iklimi. İklim, iş çevresinin psikolojik olarak önemli yönlerinin paylaşılan bir algılaması olarak tanımlanabilir (Ashforth, 1985). Scott ve Bruce (1994) iklimi "durumun, psikolojik olarak anlamlı yorumlarını yansıtan" anlamında, örgütsel oluşuma dair bireyin bilişsel (algısal) tasvirleri olarak tanımlamaktadırlar. Bilişsel bir yorum olan iklim (Scott ve Bruce, 1994 ); çalışanların iş çevrelerini algılarını ve yorumlamalarını yansıtan birey seviyesinde bir durum olarak kavramlaştırılabilir (Smidts vd., 2001).

İklimin; başarı tanımı, değerlendirmenin doğası ve temeli, hatalara verilen tepkiler bireylerin grup içi iletişim şekilleri, davranış beklentileri gibi belirleyicileri bulunmaktadır. Algılanan ego iklimi; hataların cezalandırılması, koç tarafından tanınma, daha iyi olanın pekiştirilmesi, takım içi rekabet gibi boyutlarla ifade edilmekteyken; algılanan görev iklimi; çok çalışmanın ve gelişim göstermenin değer görmesi, takım içinde her üyenin rolünün önemli olması gibi boyutlarla ifade edilmektedir (Newton vd., 2000).

İlk kez Freudenberger (1974) tarafından "bitmek, tükenmek veya enerjinin, gücün veya kaynakların aşırı talepler nedeniyle tükenmesi" biçiminde tanımlanan tükenmişlik kavramı, bireyin kendi sorunu olarak gören geleneksel görüşe göre kişisel özelliklerle ilgilidir. Kişisel özelliklerin yanı sıra farklı örgütsel faktörlerin de tükenmişlik üzerine etkili olabileceği, iş ortamında insan faktörüne yönelik düzenlemelerle tükenmişliğin azaltılabileceği iddia 
edilmektedir (Maslach vd., 2001). Bireylerin işleri dolayısıyla karşılaştıkları kişilere karşı duyarsızlaşmaIarı, kendilerini duygusal açıdan tükenmiş, başarısız ve yetersiz hissetmeleri biçiminde tanımlanan tükenmişliğin boyutları; 'duygusal tükenme, duyarsızlaşma ve düşük kişisel başarı' olarak kabul görmektedir (Ergin, 1992). Kişilerin duygusal kaynaklarının tükenmesi ve enerjisizlikle karakterize duygu durumları olarak tanımlanan duygusal tükenmişlikte çalışanlar psikolojik olarak kendilerini işe veremediklerini hissetmeleriyle, duyarsızlaşma da kişinin hizmet verdiği kişiler hakkındaki negatif, alaycı tutum ve duygularıyla karakterizedir. Bu aşamada duyarsızlaşan çalışan hizmet verdiği kişilerin bir şekilde bunu hak ettiklerini düşünür (Wright ve Bonett, 1997). Kişinin kendini negatif değerlendirme eğilimi anlamına gelen düşük kişisel başarı hissi (Maslach, Schaufeli, ve Leiter, 2001; Wright ve Bonett, 1997) kişinin işle ilgili başarısına dair artan memnuniyetsizliği ve işle ilgili ilerlemesini minimal düzeyde görme algısındaki artışla birlikte deneyimlenir (Wright ve Bonett, 1997). Dış kontrol odaklı olma, yetersizlik hissi, gerçekçi olmayan hedefler vs. gibi özellikler tükenmişliğe etki eden bireysel özellikler arasında sayılabilir. Kişisel özelliklerle birlikte işe dair stresler, sosyal ve durumsal kaynaklar gibi örgütsel özelliklerin de tükenmişliğe yol açacağı (Dalkılıç, 2014) ve tükenmişliğin, iş ortamı ve iş görenin yapısı arasındaki uyumsuzluk durumunda artış eğilimi taşıyacağı ileri sürülmektedir. Maslach ve Leiter'a göre tükenmişlik için uygun ortam yaratan örgüt iklimi sorunun bir parçası olarak görülmektedir (aktaran, Dalkılıç, 2014).

Higgins bireylerin farklı amaç yönelimine ve farklı araçlara (durumsal faktörlere) sahip olarak aynı amaç eylemini sürdürebileceğini ileri sürmektedir (Higgins, 2000). Vinacke(1962) 'ye göre motivasyonel şartlar, tepkileri tayin eden etkenlerin meydana getirdiği organize bir sistem halindedir ve bu etkenler birbirleriyle anlamlı bir ilişki içindedirler (aktaran, Arık, 1996). Benzer şekilde, "İnsanların bir eyleme katılım araçları onların amaç yönelimleriyle... birlikte devam ettiğinde insanların tecrübe ettiği şeyin düzenleyici uyum" olduğunu ileri süren Higgins bütün değerlerin acı ve memnunluk gibi karşı etkilenmelerin bir tecrübesi olduğunu söylerken yoğunluğun ise 1) katılımın gücü ve 2) acı ve memnuniyetin gücünden oluşan iki faktörün fonksiyonu olduğunu ileri sürer (2005). Higgins'a göre, düzenleyici uyum; katılımın gücünü artırarak değere katkı yapar, kişinin yaptığı her ne ise onun değerli olduğunu düşünmesini ve onun hakkında kişinin kendini iyi hissetmesini sağlar ve bundan dolayı düzenleyici uyum yargılamalar, tutumlar ve davranışlar üzerinde geniş bir etkiye sahip olur. Higgins'a göre, insanlar bir amaç peşine düştüklerinde motivasyon yönelimi, kaygı veya ilgiyle yola koyulur ve insanlar amaç peşinden giderken bazı başarılı ya da başarısız sonuçlar deneyimlemeyi umarlar (Higgins, 2005). Ego yönelimli kişiler için amaç başarı ihtiyacının tatmini iken; görev yönelimli kişiler için sorumluluk duygusuyla hareket ederek güvenlik ihtiyacının tatminidir. Ego yönelimli kişi; pozitif çıktıların varlığı ve pozitif çıktıların yokluğunu engelleyecek uygulamaların bulunduğu (ödül varlığı, hataların cezalandırılması, takım içi rekabet...) iklimde, görev yönelimli kişi ise negatif çıktıların yokluğu ve negatif çıktıların oluşmasını engelleyecek uygulamaların olduğu (çok çalışmanın, gelişimin değer görmesi, her üyenin rolünün önemli olması, takım içi destek...) iklimde uyum deneyimler (Higgins, 2000). Eğer uyum varsa yaptıkları şeye daha güçlü katılır ve kendilerini iyi hissederler (Higgins, 2005).

Ego yönelimli olan çalışanların en iyi olanların elde ettiği norm-referanslı ödülleri kazanabilmelerinin sağlanması, görev yönelimli olan çalışanlarda ise çaba sarfederek kendilerini geliştirmelerinin devamlılığının sağlanması onların tatmin düzeyleri için teoride kabul görürken; acaba bu güdülerin (ihtiyaçların) tatmin düzeyi tükenmişlik üzerinde etki yaratır mı? Gerçekten de bu güdülerin tatmin düzeyinde örgüt ikliminin (bu güdülerle uyumlu-uyumsuz) düzenleyici bir rolü var mıdır? Bu açıklamalar ışığında bu çalışmada amaç; çalışanların amaç yönelimleri ve amaç iklimi arasında düzenleyici uyumun varlığı ya da yokluğunun tükenmişlik üzerinde nasıl bir sonuç doğuracağını araştırmaktır. Bu bağlamda çalışmada, görev yönelimli çalışanların ve ego yönelimli çalışanların, ego iklimi ve görev iklimi içinde olma durumlarının onların tükenmişliği üzerinde nasıl bir etki yapacağı inceleme konusu yapılmıştır.

Çalışmanın amacı ve geliştirilen hipotez doğrultusunda oluşturulan çalışma modeli Şekil.1'de sunulmuştur. 


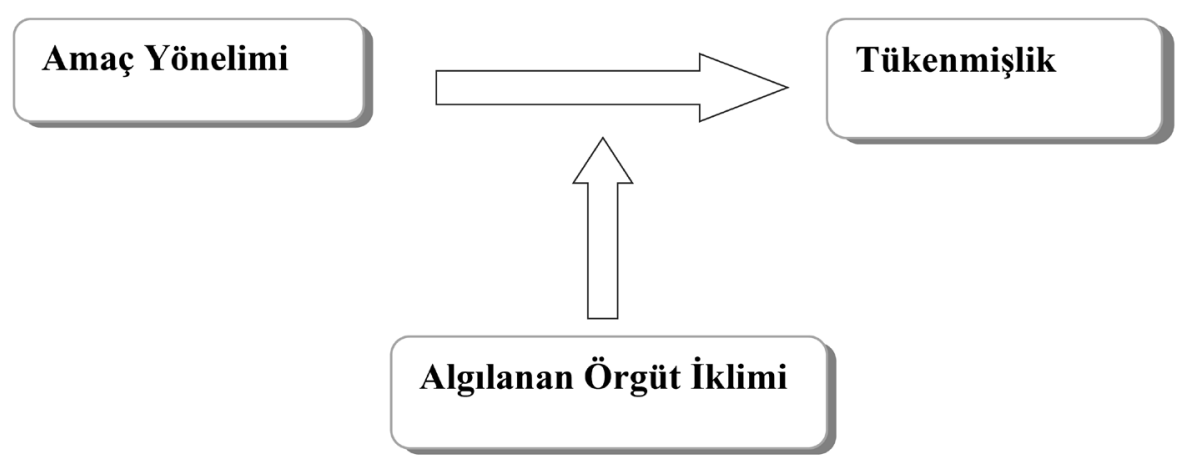

Şekil 1: Çalışmanın modeli

\section{KAVRAMSAL ÇERCEVE ve HIPOTEZLER}

Örgütün içsel iş çevresinin karakterinin, çalışan bilişi, duyguları ve davranışları üzerinde potansiyel bir etkiye sahip olduğu söylenmektedir. İklim yapısının genişve tam paylaşılan bir tanımı olmamasına rağmen, o iş çevresinin önemli yönlerinin psikolojik olarak paylaşılan algılamaları olarak tanımlanabilir. Bu tanım birkaç noktaya vurgu yapar: a) iklim soyut temelli bir algıdır ve b) iklim algılamaları kişilerin kaygılarına dönük psikolojik anlamı olan şeyleri yansıtır (Ashforth 1985). Ames ve Archer (1986) bireylerin başarı amacı yönelimlerinin kişiselliğin yanında koşul bağımlılıkların da bir eylemi olarak farklılık arz edeceğini ileri sürmüştür. Ames ve Archer'ın (1986) ifade ettiği örnek iş hayatı setine uyumlaştırılırsa; bir iş yerinde çalışanlar arasında mukayesenin vurgulanması durumunda; çalışanların, kabiliyetleri üzerine odaklanacağı ve karşıt şekilde tamamıla standartların, kişisel gelişimin ya da katılımcılığın vurgulanması durumunda çalışanların, görev stratejilerine ve çabalarına daha çok odaklanacağı ileri sürülebilir. Konuyla bağlantılı biçimde Duda (1989) da sportif faaliyet alanında, "atletler arasında sporun amacıyla ilişkili olan inançlarının atletin hüner uzmanlığı ve kişisel gelişim (bir görev yönelimi) ya da diğerlerinden daha iyi olma (bir ego yönelimi) üzerinde odaklanıp odaklanmadığına bağlı olarak belirlendiğini" bulmuştur. Bu bağlamda, güdüler amaçlar temelinde belirleniyorsa ve davranışın belirleyicileri iseler ve aynı zamanda da amaçlargüdüler koşul bağımlılık arz ediyorsa iş hayatı setinde nasıl bir ilişki biçimi ortaya çıkartırlar ve çalışanların sonuç değişkenleri üzerinde nasıl bir etki yaratırlar sorusu akla gelmektedir. Sosyal bilişsel teorilerin esası insanların kendi gerçekliklerinin aktif kurucuları olduğu fikridir. Bandura'ya (2009) göre, kişiler yaşamlarını etkileyen olaylar üzerinde kontrol sahibi olmak için çabalarlar. Bu çabayla arzu edilen geleceği gerçekleştirmek, arzu edilmeyeni engellemek mümkün olabilmektedir. Yaşam koşulları üzerinde etki sahibi olabilmek sonuçları öngörebilmeyi, bu da duygusal olarak hazır olmayı geliştirir (Bandura, 2009). Bu bağlamda çalışanlar kendilerini etkileyen olaylar üzerinde kontrollerini kaybederlerse bir kaygı bir tükenmişlik durumu yaşarlar mı? Sportif alanda geliştirilen rekabetçi kaygı teorisi (Martens vd., 1990) rekabetçi kaygının nedenini; çıktı ve çıktının önemi hakkındaki belirsizliğin karşılıklı bir eylemi olarak varsayar. Çalışma ortamının doğası gereği var olan rekabetçi ortamda çalışanlar kendilerini amaç yönelimleriyle uyumlu ya da uyumlu olmayan iklim içinde bulurlarsa ne olur? Bu uyum ya da uyumsuzluk durumu bir tükenmişlik yaratır mı?

Ames ve Archer'in (1988) öğrencilerle yaptığı çalışmada sınıfta görev iklimi algılayan üyelerce daha etkili stratejiler kullanıldığını, zorlu görevlerin tercih edildiğini, sınıfa karşı daha olumlu tutumların olduğunu ve bu öğrencilerin çabanın arkasından başarının geleceğine dair güçlü bir inançları olduğunu ifade etmişlerdir. Bu bulgu amaç yönelimi ve amaç iklimi uyumunun olumlu sonuçlarına işaret etmektedir. Araştırma bulgularına göre uyumsuzluk durumunda, performans hedeflerinin belirgin biçimde yeteneklerine odaklandığını algılayan üyeler becerilerini olumsuz değerlendirmekte ve başarısızlığı beceri eksikliğine atfetmektedirler (Ames ve Archer, 1988). Higgins de çalışmasında, bireylerin yönelimlerine uygun olan araçlar ile bir amaç izlediklerinde, yönelimleriyle uyum sağlamayan araçlarla izledikleri amaçlar için yaptıklarından çok 
daha güçlü bir şekilde o amaç eylemine katılım sağlayacaklarını ileri sürmektedir. Bireylerin amaç eylemlerinin araçları, onların yönelimleriyle uyumlu olduğunda onların, eyleme karşı ayrıca güçlü bir değerlendirici tepki yaşayacaklarını ve düzenleyici uyumun, onların eylem için hem olumlu hem de olumsuz tepkileri hakkında kendilerini iyi hissetmelerini sağlayacağını belirtmektedir (Higgins, 2005).

Yukarıdaki teorik açıklamalar ve olgusal çalışmalar bağlamında; iş gören amaç yönelimine uygun olan iklim içinde düzenleyici uyumu tecrübe edeceği ve bu uyum onların yaptığı şeyin değerini artıracağı bu bağlamda da çalışanın düşük seviyeli tükenmişlik yaşayacağı ileri sürülebilir. İş görenin amaç yönelimi ve iklim arasında düzenleyici uyum tecrübe etmediğinde de çalışan için yapılan işin değerinin düşeceği ve yüksek düzeyli tükenmişlikle karşı karşıya kalacağı iddia edilebilir. Higgins'ın düzenleyici odak teorisi bağlamında (2000); görev yönelimli çalışanlar için, çaba sarf ederek kendilerini geliştirmelerinin devamlılığını sağlayacak görev iklimi, ego yönelimli çalışanlar için en iyi olmayı sağlayan norm-referanslı ödüllerin elde edilebilirliğini sağlayan ego iklimi koşullarının sağlanmasıyla çıktılar üzerindeki belirsizlikler ortadan kaldırılarak, çalışanların tükenmişlikten korunabileceği iddia edilebilir. Bu açıklamalar ışığında çalışmamızın hipotezi aşağıdaki gibi belirlenmiştir.

Hipotez 1: Çalışanın amaç yönelimi ve algılanan iklim arasındaki uyum tükenmişlikle negatif yönlü bir ilişkide olacaktır.

\section{METODOLOJI}

\section{1. Örneklem}

Birey düzeyinde yürütülen araştırmanın evrenini Türkiye'de görev yapmakta olan banka çalışanları oluşturmaktadır. Veri toplama aşamasında banka çalışanlarına yüzyüze görüşme, e-posta ve sosyal medya gibi kanallarla ulaşılmış, çalışmaya katılmayı kabul eden banka çalışanları tarafından anketler doldurulmuştur. Veri toplama aşaması sonucunda, kayıp veri içermeyen ve sağlıklı bir şekilde doldurulmuş toplam 400 adet anket çalışmanın örneklemini oluşturmuştur. Ankete katılan banka çalışanlarının yaklaşık üçte ikisi $(61,8 \%)$ kadın iken çoğunluğu 2435 yaş aralığında (69\%) olup; yaklaşık \%76'sı lisans mezunudur.

\section{2. Ölçme}

Bağımlı Değişken; çalışmanın bağımlı değişkenini oluşturan tükenmişlik kavramının ölçülmesi için Maslach ve Jackson (1981) tarafından geliştirilen 22 sorudan oluşan İnsani Hizmetler Anketi Formu (MBI-Human Services Survey) kullanılmıştır. Bu envanter; duygusal tükenme boyutunu ölçen dokuz soru, duyarsızlaşma alt boyutunu ölçen beş soru ve kişisel başarı alt boyutunu ölçen sekiz sorudan oluşmaktadır. Beş noktalı likert tipi tepki skalası (Hiç bir zaman, Çok Nadir, Bazen, Çoğu Zaman, Her Zaman) üzerinde ölçülen, duygusal tükenme ve duyarsızlaşma boyutları için yüksek skorlar yüksek tükenmeyi ifade ederken, kişisel başarı boyutundan alınan düşük puanlar tükenmişlik göstergesi olarak yorumlanmaktadır. Tükenmişlik ölçeğinin yapı geçerliliğine kanıt sağlamak üzere uygulanan keşfedici faktör analizi uygulanmış ve birbirinden bağımsız alt skalalar üretebilmek amacı ile orthogonal faktör rotasyonu (varimax yöntemi) kullanılmıştır. Faktör analizi sırasında, kişisel başarı boyutundan 1 adet soru ve duyarsızlaşma boyutundan 3 soru, aynı anda birden fazla faktöre yüklendikleri (binişik) veya kuramsal beklentilere aykırı şekilde farklı faktör altında toplandıkları için ölçekten çıkarılmıştır. Kalan maddeler için kuramsal beklentilere uygun şekilde üç boyutlu bir yapı elde edilmiş olup Tablo 1'de görüldüğü üzere bu yapıyı oluşturan maddelerin faktör yükleri 0,572 (en düşük) ila 0,847 (en yüksek) aralığında değişmektedir. Elde edilen üç faktörlü yapı toplam varyansın \%58,83'ünü açıklamaktadır. Uygulanan $\mathrm{KMO}(0,896)$ ve Barlett's küresellik testleri $(\mathrm{P}<, 01)$ verilerin faktör analizine uygun olduğunu göstermektedir. Tükenmişlik ölçeğinin içsel tutarlılığına kanıt sağlamak üzere uygulanan güvenilirlik analizi sonucunda elde edilen Cronbach's Alpha istatistikleri, duygusal tükenme $(a=, 913)$, kişisel başarı $(a=, 802)$ ve duyarsızlaşma $(a=, 720)$ boyutlarının her biri için beklenen düzeyde güvenilirlikten bahsedilebileceğini göstermektedir. 
Tablo 1: Tükenmişlik Ölçeğinin Faktör Analizi ve Güvenirlik Analiz Sonuçları

\begin{tabular}{ll}
\hline Ölçek Maddeleri & Duygusal Kişisel Duyarsız- \\
& Tükenme Başarı laşma \\
\hline
\end{tabular}

TK2_DT İş dönüşü kendimi ruhen tükenmiş hissediyorum

, 847

TK1_DT İşimden soğuduğumu hissediyorum $\quad$ 828

TK8_DT Yaptığım işten yıldığımı hissediyorum $\quad$ 826

TK3_DT Sabah kalktığımda, bir gün daha bu işi kaldıramayacağımı hissediyorum

TK13_DT İşimin beni kısıtladığını hissediyorum

TK14_DT İşimde çok fazla çalıştığımı hissediyorum

TK20_DT Kendimi çok çaresiz hissediyorum

,648

TK6_DT Bütün gün insanlarla uğraşmak benim için gerçekten çok yıpratıcıdır

TK16_DT Doğrudan doğruya insanlarla çalışmak, bende çok fazla stres yaratıyor

TK19_KB Bu işte kayda değer birçok başarı elde ettim

, 767

TK17_KB İşim gereği karşılaştığım insanlarla aramda rahat bir atmosfer yaratırım

, 721

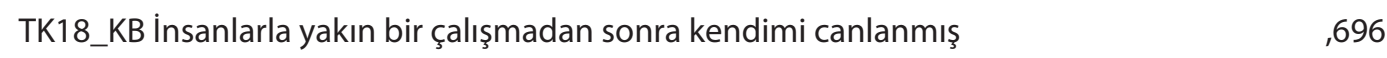

hissederim

, 656

TK21_KB İşimdeki duygusal sorunlara serinkanlılıkla yaklaşııım

, 651

TK7_KB .İ̧sim gereği karşılaştığım insanların sorunlarına en uygun çözüm

TK12_KB Çok şeyler yapabilecek güçteyim

TK9_KB Yaptığım iş sayesinde insanların yaşamına katkıda bulunduğuma , 608 inanıyorum

TK15_DY İşim gereği karşılaştığım insanlara ne olduğu umurumda değil. TK5_DY İşim gereği karşılaştığım bazı kimselere sanki kişilikten yoksun objeymiş gibi davrandığımı fark ediyorum

, 819

Açıklanan Toplam Varyans

$30,016 \quad 18,650$

10,164

Cronbach's Alpha

,913 802 , 720 
Bağımsız Değişken; Çalışmanın bağımsız değişkenini oluşturan amaç (ego ve görev) yönelimi, Roberts vd. $(1998,339)$ tarafından, sporcuların başarı hedeflerini açıklamak amacıyla geliştirilen algılanan başarı ölçeği araştırma örneklemini oluşturan banka çalışanlarına uyarlanarak ölçülmüştür. Ölçeğin Türkçeye uyarlanması sırasında Türkçe çeviride anlamı farklılaştırılamayan sorulardan biri ölçekten çıkarılmış ve 6'sı görev yönelimini, 5'i ise ego yönelimini ölçmeye yarayan 11 adet soru bağımsız değişkenlerin ölçümü için kullanıımıştır. Bu sorular 1 (en düşük) ile 5 (en yüksek) arasında değerler alabilen likert tipi skala (kesinlikle katılmıyorum, .... , kesinlikle katılıyorum) üzerinde ölçülmüştür. Uygulanan keşfedici faktör analizi sırasında ego yönelimini ölçmeye yarayan bir soru ölçekten çıkarılmış ve kalan soruların Tablo 2'de görüldüğü üzere kuramsal beklentilerle uyumlu iki boyutlu bir yapı oluşturdukları görülmüştür. Toplam varyansın \%72'sini oluşturan bu yapıyı oluşturan soruların faktör yükleri 0,587 (en düşük) ile 0,901 (en yüksek) aralığında değişmekte ve uygulanan KMO $(0,898)$ ve Barlett's küresellik testleri $(P<, 01)$ verilerin faktör analizine uygunluğuna kanıt sağlamaktadır. Görev yönelimi $(a=, 906)$ ve ego yönelimi $(\alpha=, 885)$ boyutlarının her ikisi için de yeterli bir güvenilirlik düzeyi sağlanmıştır.

Tablo 2: Algılanan Başarı Ölçeğinin Faktör Analizi ve Güvenirlik Analiz Sonuçları

\section{Ölçek Maddeleri}

BA11Elimden gelenin en iyisini yaptığımda

BA8 Zorlukların üstesinden geldiğimde

BA5 Ciddi düzeyde kişisel gelişim gösterdiğimde

BA9 Kişisel amaçlarıma ulaştığımda

BA4 Sıkı çalıştığımda

BA7 Bana verilen hedefleri tutturduğumda

BA2 Açık ara üstün durumda olduğumda

BA1 Rakiplerimi yendiğimde

BA6 Rakiplerimden daha iyi performans gösterdiğimde

BA10Diğer insanlara en iyi olduğumu gösterdiğimde
Görev Yön.

, 893

, 878

, 820

, 819

, 632

, 587

Açıklanan Toplam Varyans

39,890

Düzenleyici Değişken: Sporcuların takımlarındaki ego ve görev yönelimli iklimi algılarında bireysel farklıııkları ölçmeye yönelik olarak geliştirilmiş olan; 33 sorudan oluşmuş ölçek (Newton vd.,2000) soruların birebir Türkçe'ye çevrilmesi sonucunda anlamı birbiriyle örtüşen iki soru bulunduğundan, 19 no'lu soru çıkarılarak 32 soru alınmış ve banka çalışanlarına göre uyarlanmıştır. Katılımcılardan soruları 5'li likert (kesinlikle katılmıyorum, .... , kesinlikle katılıyorum) ölçeği üzerinde cevaplandırmaları istenmiştir. Uygulanan keşfedici faktör analizi sonucunda, ölçeğin yapı geçerliliğini olumsuz etkileyen sorular ölçekten çıkarılmış ve görev yönelimli örgüt iklimi (12 soru) ile ego yönelimli örgüt iklimi (11 soru) sorularının ayrı faktörler altında toplandıkları iki boyutlu bir yapı elde edilmiş ve Tablo 3'te gösterilmiştir.. Toplam varyansın 0,54'ünü açıklayan bu yapı için elde edilen KMO $(0,920)$ ve Barlett's küresellik testleri $(\mathrm{P}<, 01)$ de beklenen değerleri almıştır. Güvenilirlik katsayıları görev yönelimli örgüt iklimi için $a=, 928$ ve ego yönelimli örgüt iklimi için $a=, 901$ olarak hesaplanmıştır. 
Tablo 3: Algılanan Motivasyonel İklim Ölçeğinin Faktör Analizi ve Güvenirlik Analiz Sonuçları

\begin{tabular}{|c|c|c|}
\hline Ölçek Maddeleri & $\begin{array}{l}\text { Görev } \\
\text { İklimi }\end{array}$ & $\begin{array}{l}\text { Ego } \\
\text { İlimi }\end{array}$ \\
\hline Öi20 Işyerimde yöneticim çalışanların birbirlerini desteklemesini teşvik eder & 814 & \\
\hline Öi30 İşyerimde çalışanlar; tam bir ekip ruhuyla çalışır & 809 & \\
\hline Öi32 İsyerimde çalışanlar; en iyiyi ve mükemmeli yakalamak için birbirlerine yardım eder & 800 & \\
\hline Öi111 İşyerimde çalışanlar birbirlerinin işi öğrenmesine yardım eder & ,776 & \\
\hline Öi27 İşyerimde; çalışanların zayıf yönlerini güçlendirmeleri teşvik edilir & ,745 & \\
\hline Öi31 İşyerimde çalışanlar kendilerini ekibin en önemli üyesiymiş gibi hissederler & ,742 & \\
\hline Öi10 Işyerimde, her seviyedeki çalışan önemli bir role sahiptir & ,739 & \\
\hline Öi29 Işyerimde odak noktası, her iş uygulamasını geliştirmektedir & ,738 & \\
\hline Öi5 Yöneticim ekip başarısında her çalışanın hayati olduğuna inanır & ,726 & \\
\hline $\begin{array}{l}\text { Öi14 İşyerimde yöneticim çalışanların iyi olmadıkları becerileri geliştirdiklerinden } \\
\text { emindir }\end{array}$ & 695 & \\
\hline Öi4 İşyerimde her çalışan şubeye/ birime önemli bir şekilde katkıda bulunur & 692 & \\
\hline $\begin{array}{l}\text { Öi8 İşyerimde ekip arkadaşlarım ellerinden gelenin en iyisini yaptıklarında kendilerini } \\
\text { iyi hissederler }\end{array}$ & 678 & \\
\hline Öi15Yöneticim işyerindeki karmaşıklıklardan dolayı çalışanları azarlar & & ,790 \\
\hline Öi2 Işyerimde çalışanlardan biri hata yaptığında yönetici çılgına döner & & ,750 \\
\hline Öi18 İşyerimde çalışanlar hata yaptıklarında cezalandırılır & & ,738 \\
\hline Öi28 Işyerimde, yönetici bazı çalışanları kayııır & & ,732 \\
\hline $\begin{array}{l}\text { Öi7 İşyerimde yöneticim sadece en iyi olan çalışanın şube/birim başarısına katkıda } \\
\text { bulunduğunu düşünür }\end{array}$ & & ,729 \\
\hline Öi17 İşyerimde sadece rakamsal hedeflerini tutturan çalışanlar övgü alır & & ,721 \\
\hline Öi23 İşyerimde çalışmak istiyorsan en iyi çalışanlardan biri olmalısın & & ,685 \\
\hline Öi26 İşyerimde çalışanlar hata yapmaktan korkar & & ,676 \\
\hline Öi21 İşyerimde yöneticim en iyi çalışanın kim olduğunu düşündüğünü açıkça belli eder & ,668 & \\
\hline Öí Yöneticim çalışanları sadece diğer çalışanlardan daha başarılı olduklarında över & 667 & \\
\hline Öị İşyerimde, çalışanlar hatalarından dolayı işlerini kaybeder & & ,633 \\
\hline Açıklanan Toplam Varyans & 29,811 & 24,586 \\
\hline Cronbach's Alpha & ,928 & 901 \\
\hline
\end{tabular}

\subsection{Verilerin Analizi}

Çalışmanın değişkenleri arasındaki ilişkiler hakkında ön bilgi elde etmek amacıyla öncelikle korelason analizi yapılmış ve değişkenler arasında çoklu doğrusal bağıntı problemi olup olmadığı araştırılmıştır. Tablo 1'de ilişki katsayılarının orta düzeyde bulunması böyle bir bağıntının olmadığını göstermektedir. Çoklu doğrusal bağıntı probleminin tespitine yönelik ayrıca varyans arttırıcı faktörler (VIF) kullanılmıştır. VIF değerleri 10'dan küçüktür. VIF değerinin 10 'dan küçük olması çoklu doğrusal bağıntı probleminin olmadığına kanıt sağlamaktadır (Albayrak, 2005). 
Tablo 4: Korelasyon Tablosu

\begin{tabular}{llllllllll}
\hline & & & 1 & 2 & 3 & 4 & 5 & 6 & 7 \\
\hline 1-GRVIKL & 3,08 &, 044 & 1 & & & & & & \\
2-EGOiKL & 2,95 &, 044 &, 097 & 1 & & & & & \\
3-DT & 3,13 &, 046 &,$- 187^{* *}$ &, $392^{* *}$ & 1 & & & & \\
4-KB & 3,58 &, 035 &, $381^{* *}$ &, $108^{*}$ &, 073 & 1 & & & \\
5-DUY & 2,34 &, 055 &, $121^{*}$ &, $316^{* *}$ &, $548^{* *}$ &, 077 & 1 & & \\
6-AY_Ego & 3,23 &, 055 &, $349^{* *}$ &, $329^{* *}$ &, 045 &, $330^{* *}$ &, 037 & 1 & \\
7-AY_Görev & 3,77 &, 052 &, $512^{* *}$ &, $335^{* *}$ &, 002 &, $357^{* *}$ &, 030 &, $607^{* *}$ & 1 \\
\hline
\end{tabular}

**. $p<0,01 \quad$ *. $P<0,05$

Ardından hipotezin test edilmesine yönelik olarak, veriler çoklu doğrusal regresyon analizi ile analiz edilmiştir. Hipotez edilen moderatör ilişkinin test edilmesinde Baron ve Kenny (1986) çalışması referans alınmıştır. Buna göre amaç (ego ve görev) yönelimi ile tükenmişlik arasındaki ilişsinin yönünün veya büyüklüğünün ego ve görev yönelimli örgüt iklimlerinin düşük ve yüksek düzeyleri için farklılaşacağına dair öngörünün sınanması için bağımsız değişken ile bağımlı değişken arasındaki etkileşimin anlamlıı̆ıının yorumlanması gerekmektedir.

Amaç yöneliminin tükenmişlik üzerindeki etkisi ve algılanan motivasyonel iklimin moderatör rolünün incelenmesi için kurgulanan regresyon modellerinde:

Amaç Yönelimi (Ego ve Görev Yönelimi ); bağımsız değişken, Algılanan Motivasyonel İklim (Ego İklimi ve Görev İklimi); moderatör (düzenleyici) değişken, Tükenmişlik (Duygusal Tükenme, Duyarsızlaşma ve Kişisel Başarı); bağımlı değişkendir.

Montgomery vd. (2013)'ne göre etkileşim etkisi içeren modeller çoklu doğrusal regresyon yöntemleriyle analiz edilebilir. Bu bilgiler ışığında;

$\mathbf{y}_{1=}$ Duygusal Tükenme, $\mathbf{y}_{2=}$ Kişisel Başarı, $\mathbf{y}_{3=}$ Duyarsızlaşma ve

$x_{1}=$ Ego Yönelimi, $x_{2}=$ Görev yönelimi, $x_{3}=$ Görev Iklimi, $\mathrm{x}_{4}=$ Ego Íklimi

olmak üzere oluşturulan ve aşağıda yer alan 18 modelin test edilmesi gerekmektedir:
Model 1: $y_{1}=\beta_{0}+\beta_{1} x_{1}+\beta_{2} x_{2}+\varepsilon$

Model 2: $y_{1}=\beta_{0}+\beta_{1} x_{1}+\beta_{2} x_{2}+\beta_{3} x_{3}+\beta_{4} x_{4}+\varepsilon$

Model 3: $y_{1}=\beta_{0}+\beta_{1} x_{1}+\beta_{2} x_{2}+\beta_{3} x_{3}+\beta_{4} x_{4}+\beta_{1,3} x_{1} x_{3}+\varepsilon$

Model 4: $y_{1}=\beta_{0}+\beta_{1} x_{1}+\beta_{2} x_{2}+\beta_{3} x_{3}+\beta_{4} x_{4}++\beta_{1,4} x_{1} x_{4}+\varepsilon$

Model 5: $y_{1}=\beta_{0}+\beta_{1} x_{1}+\beta_{2} x_{2}+\beta_{3} x_{3}+\beta_{4} x_{4}+\beta_{2,3} x_{2} x_{3}+\varepsilon$

Model 6: $y_{1}=\beta_{0}+\beta_{1} x_{1}+\beta_{2} x_{2}+\beta_{3} x_{3}+\beta_{4} x_{4}+\beta_{2,4} x_{2} x_{4}+\varepsilon$

Model 7: $y_{2}=\beta_{0}+\beta_{1} x_{1}+\beta_{2} x_{2}+\varepsilon$

Model 8: $y_{2}=\beta_{0}+\beta_{1} x_{1}+\beta_{2} x_{2}+\beta_{3} x_{3}+\beta_{4} x_{4}+\varepsilon$

Model 9: $y_{2}=\beta_{0}+\beta_{1} x_{1}+\beta_{2} x_{2}+\beta_{3} x_{3}+\beta_{4} x_{4}+\beta_{1,3} x_{1} x_{3}+\varepsilon$

Model 10: $y_{2}=\beta_{0}+\beta_{1} x_{1}+\beta_{2} x_{2}+\beta_{3} x_{3}+\beta_{4} x_{4}++\beta_{1,4} x_{1} x_{4}+\varepsilon$

Model 11: $y_{2}=\beta_{0}+\beta_{1} x_{1}+\beta_{2} x_{2}+\beta_{3} x_{3}+\beta_{4} x_{4}+\beta_{2,3} x_{2} x_{3}+\varepsilon$

Model 12: $y_{2}=\beta_{0}+\beta_{1} x_{1}+\beta_{2} x_{2}+\beta_{3} x_{3}+\beta_{4} x_{4}+\beta_{2,4} x_{2} x_{4}+\varepsilon$

Model 13: $y_{3}=\beta_{0}+\beta_{1} x_{1}+\beta_{2} x_{2}+\varepsilon$

Model 14: $y_{3}=\beta_{0}+\beta_{1} x_{1}+\beta_{2} x_{2}+\beta_{3} x_{3}+\beta_{4} x_{4}+\varepsilon$

Model 15: $y_{3}=\beta_{0}+\beta_{1} x_{1}+\beta_{2} x_{2}+\beta_{3} x_{3}+\beta_{4} x_{4}+\beta_{1,3} x_{1} x_{3}+\varepsilon$

Model 16: $y_{3}=\beta_{0}+\beta_{1} x_{1}+\beta_{2} x_{2}+\beta_{3} x_{3}+\beta_{4} x_{4}++\beta_{1,4} x_{1} x_{4}+\varepsilon$

Model 17: $y_{3}=\beta_{0}+\beta_{1} x_{1}+\beta_{2} x_{2}+\beta_{3} x_{3}+\beta_{4} x_{4}+\beta_{2,3} x_{2} x_{3}+\varepsilon$

Model 18: $y_{3}=\beta_{0}+\beta_{1} x_{1}+\beta_{2} x_{2}+\beta_{3} x_{3}+\beta_{4} x_{4}+\beta_{2,4} x_{2} x_{4}+\varepsilon$

Uygulanan regresyon analizi sonucunda, böyle bir etkileşimin sadece ego yönelimli kişilik özelliği ile ego iklimi arasındaki etkileşimin duygusal tükenme üzerindeki etkisi için anlamlı olduğunu göstermektedir (Model 4: $\beta=-, 096 ; P<, 05$ ). 
Tablo 5: Regresyon Analizi Sonuçları

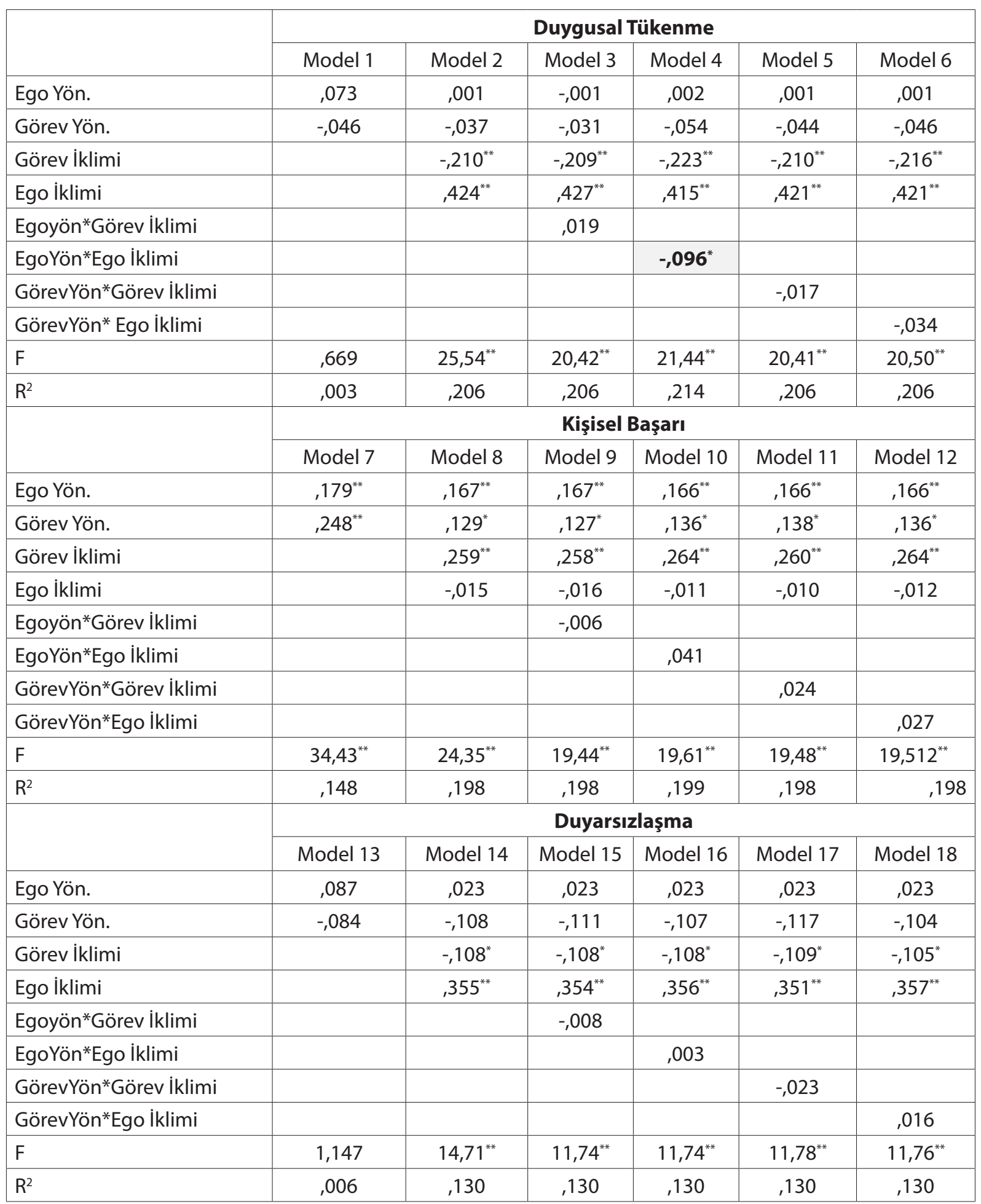

Etkileşim etkisinin Aiken ve West'in (1991) önerdiği şekilde grafikle gösterimi (aktaran; Cohen vd.,2003) Şekil 2.'de yer alan grafikteki gibidir. Ego yönelimli kişilik özelliği ile ego iklimi arasındaki etkileşimin duygusal tükenme üzerindeki etkisinin grafiksel gösterimi (Şekil 2) incelendiğinde, ego yönelimli kişilik ile duygusal tükenme arasındaki ilişkinin yüksek ego ikliminde negatif olduğu dikkat çekmektedir. Buna karşın düşük ego performans iklimi söz konusu olduğunda ego yönelimli kişilik ile duygusal tükenme arasında pozitif yönlü bir ilişki gözlenmektedir. 


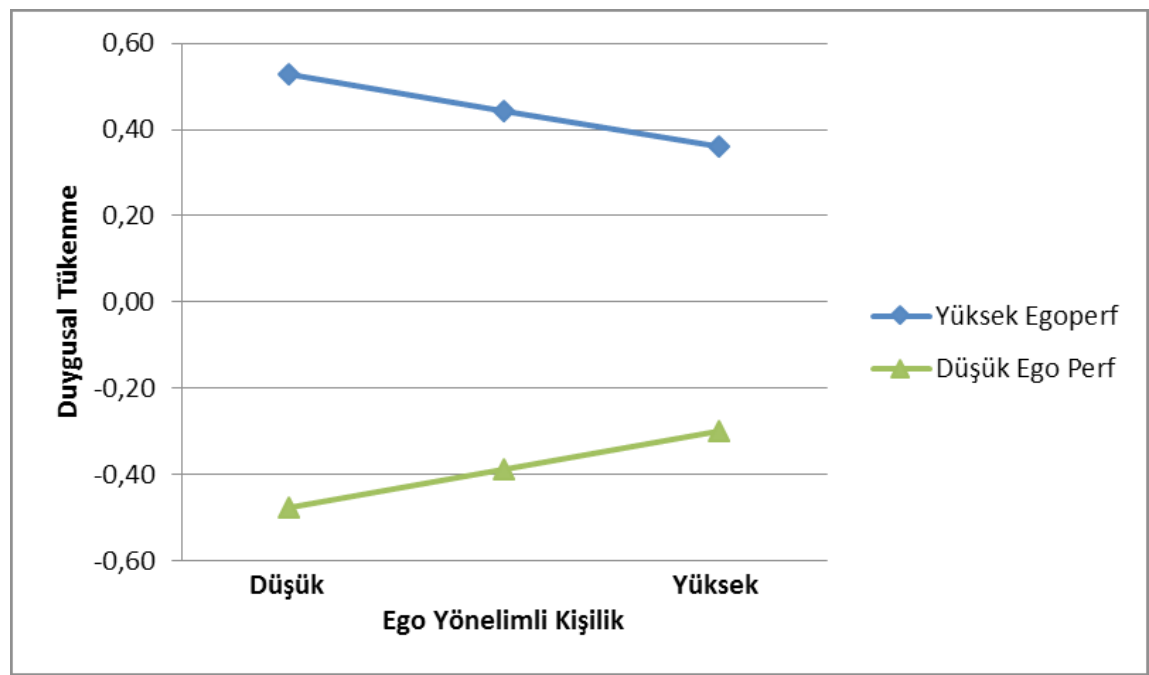

Şekil 2: Ego Yönelimli Kişilik Özelliği Ile Ego İklimi Arasındaki Etkileşim

\section{SONUÇLAR VE TARTIŞMA}

Başarıya yönelik olma ve algılanan iklim uyumunun çalışanları tükenmişlikten koruyup koruyamayacağını araştıran bu çalışmada elde edilen bulgular sadece, ego yönelimi ve ego iklimi arasındaki etkileşimin duygusal tükenmişlik üzerindeki etkisinin anlamlı olduğuna işaret etmektedir. Bu bulguya göre, çalışmada sadece ego yönelimi ve duygusal tükenmişlik arasındaki ilişkide ego ikliminin düzenleyici rolüne kanıt sağlanmıştır. Çalışmamızın ana sorunsalına bağlı olarak bu bulgu yorumlandığında, örneklemimizi oluşturan banka çalışanlarından ego yönelimine sahip olanların yüksek düzeyli ego iklimine yansıtan bir örgüt ikliminde çalışmaları durumunda duygusal tükenmişliklerinin azalacağına işaret etmektedir (Tablo 5, Model 4, Şekil 2). Bulgular, ayrıca karşıt biçimde, ego yönelimine sahip çalışanların düşük ego iklimine sahip olmaları durumunda da duygusal tükenmişliğin artacağına işaret etmektedir.

Çalışmada ulaşılan sonuçlar uygulamaya dönük yönetimci bir bakış açısıyla yorumlandığında: toplumumuzun var olan norm ya da idealleri ile örtüşecek şekilde az çabayla diğerlerini geride bırakarak yetenekli olduklarını ispatlama düşüncesinde olan ego yönelimli banka çalışanları için amaç, başarı ihtiyacını tatmin edecek olan bir ideal ve bir umut olarak algılanmaktadır. Onların amaçlarını gerçekleştirmek için pozitif çıktıların varlığını sağlayacak (hedef gerçekleştirme garantisi, ilerleme araçları sunma- rekabeti özendirmek- iyi olanın pekiştirilmesi) ve pozitif çıktıların yokluğuna karşı duracak (ihmalleri engellemek-hataların cezalandırılması-) iklime ihtiyaç vardır. Bir başka deyişle çalışma sonuçları; hataların cezalandırıldığı, bireysel rekabetin özendirildiği yüksek düzeyli ego ikliminin gerekliliğini banka yöneticilerine göstermektedir. Çalışma sonuçları, ego yönelimi ve ego iklimi arasında sağlanan düzenleyici uyumun, sadece çalışanların yaptıkları işe değer katmasıyla kalmayıp; belirsizlik durumunu ve çaresizlik hissini de ortadan kaldırarak tükenmişliği azaltılabileceğine de kanıt sağlamaktadır.

Bankalardaki yönetim uygulamalarını dile getiren Özdemir'e (2016) göre; yoğun çalışma saatleri ve fazla mesai kavramıyla bilinen bir meslek olan bankacılık son yıllarda sektördeki yabancı sermaye artışına paralel artan satış baskısıyla da anılmaktadır. Hedefe dayalı performans sistemi psikolojik taciz unsuru olarak kullanılmasıyla eleştirilmektedir. Bir önceki yılın gerçekleşen rakamları baz alınarak belirlenmesi gereken hedefler genellikle çok yüksek belirlenmekte hatta dönem içinde hedefine yaklaşanlar için hedef revizyonu söz konusu olabilmektedir. Çalışanlar genellikle hedef gerçekleştirme oranlarına göre pirimle ödüllendirilirken; hedef gerçekleşmemesi durumunda önce uyarılma, devam etmesi halinde de işten çıkarılma tehdidi ile karşı karşıya kalabilmekte ve bankaların önemli reklam verenler olmasından dolayı bankacıların sorunları basında çok fazla yer bulamayabilmektedir. Banka çalışanları sadece rakip bankalarla değil kendi bankalarının, diğer bölge ve şubeleriyle hatta aynı şube içindeki ekip arkadaşlarıyla da rekabet halindedir. Farklı isimler alsa da günün yıldızı, haftanın yıldızı, ayın şampiyonu, yıldız şube, vs gibi kampanyalarla çalışan, adeta bir 
spor müsabakasındaymışçasına her daim yarışmak zorundadır (Özdemir, 2016a; Özdemir, 2016b; 2016c; Özdemir, 2016d). Bulgularımızla örtüşen şekilde bankalarımızda, ego yönelimli çalışanların uyum sağlayabileceği iklimi temsil eden; hedef gerçekleştirme garantisi, ilerleme araçları sunma, rekabeti özendirmek, iyi olanın pekiştirilmesi, ihmalleri engellemek, hataların cezalandırılması gibi ödüller ya da işi kaybetme kaygısıyla rakamsal hedeflerin önemsendiği yoğun ego iklimi olduğu söylenebilir. Tüm bu bulgular bağlamında, bankaların ego iklimleriyle uyumlu ego yönelimli kişileri istihdam etmeleri halinde beklentilerin örtüşeceği ve çatışmaların daha az olacağı ve de tükenmişliğin daha az gerçekleşebileceği söylenebilir.

\section{KAYNAKÇA}

Albayrak, A.S. (2005) "Çoklu Doğrusal Bağlantı Halinde Enküçük Kareler Tekniğinin Alternatifi Yanlı Tahmin Teknikleri ve Bir Uygulama" ZKÜ Sosyal Bilimler Dergisi, 1(1): 105-126.

Arık, A.,(1996) Motivasyon ve Heyecana Giriş, İstanbul, Çantay Kitapevi.

Ames, C., ve Ames, R. (1981) "Competitive Versus Individualistic Goal Structures: The Salience of Past Performance Information for Causal Attributions and Affect" Journal of Educational Psychology, 73(3): 411418.

Ames, C., ve Archer, J. (1988) "Achievement Goals in the Classroom: Students' Learning Strategies and Motivation Processes" Journal of Educational Psychology, 80(3), 260-267.

Amorose, A. J., ve Horn, T. S. (2000) "Instrinsic Motivation:Relationships With Collegiate Athlets' Gender Scholarship Status, and Perceptions of Their Coaches' Behavior" Journal of SportveExercise Psychology (22): 63-84.

Ashforth B.E. (1985) "Climate formations: İssues and Extensions" Academy of Management Review, 10 (4): 837-847.

Bandura, A. (2009) Cultivate Self-Efficacy for Personal, E. A. Locke (Ed.): Handbook of Principles of Organizational Behavior, 2.ed., West Sussex, Willey.

Baron, R. M., ve Kenny, D. A. (1986) "The ModeratorMediator Variable Distinction in Social Psychological Research: Conceptual, Strategic, and Statistical Considerations" Journal of Personality and Social Psychology, 51 (6): 1173-1182.

Cohen, J., Cohen, P., West, S. G., \& Aiken, L. S. (2003). Applied Multiple Regression/Correlation Analysis for the Behavioral Sciences (3. ed.). New Jersey: Lawrence Erlbaum Associates.

Dalkılıç, O.S. (2014) Çalışma Hayatında Tükenmişlik Sendromu. 2.b., Ankara, Nobel.

Deci, E. L. (1971)“Effect of Externally Mediated Rewards on Insrinsic Motivation". Journal of Personality and Social Psychology, 18(1), 105-115.
Deci, E. L. (1972) "Intrınsıc Motıvatıon, Extrınsıc Reınforcement, And Inequity" Journal oj Personality and Social Psychology, 22(1): 113-120.

Duda, J. L. (1989) "Relationship Between Task and Ego Orientation and the Perceived Purpose of Sport Among High School Athletes" Journal of Sport \& Exercise Psychology, (11): 318-335.

Dweck, C. S.( 1986) "Motivational Processes Affecting Learning" American Psychologist, 41 (10): 1040-1048.

Dweck, C. S.,Leggett, E. L. (1988) "A SocialCognitive Approach to Motivation and Personality" Psychological Review, 95(2): 256-273.

Elliot, A. J. (2005) A Conceptual History of the Achievement Goal Construct. A. J. Elliot, C. S. Dweck (Ed.), Handbook of Competence and Motivation, New York, The Guilford Press.

Ergin, C. (1992) "Doktor ve Hemşirelerde Tükenmişlik ve Maslach Tükenmişlik Ölçeğinin Uyarlanması" VII. Psikoloji Kongresi Bilimsel Çalışmaları, 22(25): 143-154.

Freudenberger, H. J.( 1974) "Staff Burn-Out" Journal Of Social Issues, 30(1,): 158-165.

Higgins, E. (2000) "Making A Good Decision: Value From Fit" American Psychologist, 55(11): 1217-1230.

Higgins, E. (2005) "Value From Regulatory Fit" American Psychological Society, 14(4): 209-213.

Jagacinski, C. M., Nicholls, J. G. (1984) “Conceptions of Ability and Related Affects in Task Involvement and Ego Involvement" Journal of Educational Psychology, 76(5): 909-919.

Martens, R., S.Vealey, R., Burton, D. (1990) Competetive Anxiety in Sport, Champaign, Human Kinetics.

Montgomery, D. C., Peck, E.A., ve Vining, G. (2013). Doğrusal Regresyon Analizine Giriş (5 b.). (A. Erar, Çev.) Ankara: Nobel.

Maslach, C., Jackson, S. E. (1981) "The measurement of experienced burnout" Journal Of Occupational Behaviour, 2: 99-113.

Maslach, C., Schaufeli, W. B., Leiter, M. P. (2001) "Job Burnout" Annual Review of Psychology, 52: 397-422. 
Maslow, A. H. (1943) "A Theory Of Human Motivation" Psychological Review, 50: 370-396.

McClelland, D. C. (1970) "The Two Faces of Power" Journal of International Affairs, 24(1): 29-47.

Murray, H. A. (2008) Exploration in Personality, 70th Anniversary Edition,New York: Oxford University Press.

Newton, M., Duda, J. L., Yin, Z. (2000) "Examination Of The Psychometric Properties Of The Perceived Motivational Climate in Sport Questionnaire - 2 in a sample of female athletes" Journal of Sports Sciences, 18: 275-290.

Nicholls, J. G. (1978) "The Development of the Concepts of Effort and Ability, Perception of Academic Attainment,and the Understanding That Difficult Tasks Require More Ability" Child Development, 49: 800-814.

Özdemir, R. (2016) http://www.yenicaggazetesi.com. tr/bankaci-nasil-sifirlanir-38152yy.htm (14.05.2016).

Özdemir, R. (2016). http://www.yenicaggazetesi.com. tr/basinin-banka-korkusu38615-yy.htm (20.06.2016).

Özdemir, R. (2016) http://www.yenicaggazetesi. com.tr/kac-bankaci-daha-olmeli-38256yy.htm (23.05.2016).
Özdemir, R. (2016) http://www.yenicaggazetesi. com.tr/tencere-tava-bankaciligi-38895yy.htm (11.07.2016).

Roberts, G. C., Treasure, D. C., Balague, G. (1998) "Achievement Goals in Sport: The Development and Validation of the Perception of Success Questionnaire" Journal of Sports Sciences, 16: 337-347.

Scott, S.G., Bruce, R. A. (1994) "Determinants Of Innovative Behavior: A Path Model Of Individual Innovation in the Workplace" Academy of Management Journal, 37(3): 580-607

Smidts, A., Pruyn H., Riel C. B. (2001) "The Impact of Employee Communication and Perceived External Prestige on Organizational Identification" The Academy of Management Journal,44(5):1051-1062.

Snyder, M. (1993) "Basic Research and Practical Problems: The Promise of a "Functional" Personality and Social Psychology" Personallity and Social Psychology Bulletin, 19: 251-264.

Wright, T. A., ve Bonett, D. G. (1997) “The Contribution of Burnout to Work Performance" Journal of Organizational Behavior, 18: 491-499.

Wyner, D. R (2004) “Personal and Situational Factors Associated with Collagiate Athlete Burnout: An Achievement Goal Theory Perspective" Ph.D. Thesis, Emory University, Atlanta. 
